\title{
AN OVERVIEN OF LITERATURE ON HUMAN FACTORS AND PART-TASK TRAINING WITH IMPLICATIONS FOR VISUAL SIMULATION IN PRIMARY FLIGHT TRAINING
}

Richard A. Kraemer

Miami-Dade Community College South Campus

11011 S.W. 104th St., Miami, Fla. 33176 (305) 596-1157

June 5, 1984 


\begin{abstract}
Research issues are identified through the application of a conceptual model of human factors interactions in pilot performance. The application of parttask training concepts and methodology shows that simulation has a great potential to address pilot training research design issues. This and new technologies indicate that the best medium for the cost effective application of part-task training methodology would be a computer generated video graphics display. The U.S. college and university aviation programs have all the ingredients on hand to deyelop this training device and the best minds with which to do it. Appendices hold collections of references for those interested in these subjects.
\end{abstract}




\section{Introduction:}

Great progress in reducing general aviation accidents has been made. These accomplishments are hampered by the fact that the percentage of continuing accidents attributed to pilot error remains at nearly $80 \% .^{1}$ During the past decade the FAA has undertaken a broad systems approach to study the factors affecting pilot performance. This has led to an embracing of the body of human factors knowledge and the use of a human factors approach to research. ${ }^{2}$

There is a large body of human factors knowledge and research concerning the concept of part-task training. Part-task training involves the practice of some subsets of components of a whole task prior to practice or performance of that whole task. ${ }^{3}$ Flight simulation and particularly visual flight simulation shows new promise for enhanced effectiveness using part-task principles. ${ }^{4}$

Major technological advances have greatly reduced the cost of hi-fidelity color video motion recording and playing equipment. Computer generated video systems capable of simulating out-of-cockpit views in flight are presently available even at the personal computer market level. 5 The FAA has waived some of the minimum flight time requirements for specifically approved college level general aviation training programs. This and the high cost of flight trainina in aircraft has opened the door to innovation in cost effective alternatives that reduce flight time needed to achieve performance standards. Visual simulation appears ripe for innovation.

This work initially presents an overview of recent work that has identified a systematic framework for research into human factors affecting pilot performance A compilation of pertinent references from literature reviews and papers on this subject for general aviation is presented in appendix $A$. The appendix is for the convenience of those interested in human factors knowledge as it is applied to gen. eral aviation. Next an overview of part-task training theory and methodology is presented. Then there is a review of current aviation research on part-task 
training of pilots with flight simulators that have visual systems. A compilation of pertinent references on part-task training applicable to aviation is presented in appendix $B$.

Finally the potential for visual simulation to improve pilot performance in primary flight training is discussed. The present use of visual simulation systems in primary flight training is reviewed in the light of a human factors approach. Part-task training methodology applications are hypothesized and recommendations for further research are made.

\section{Human Factors Problems In Pilot Performance}

The all encompassing "pilot error" cause for accidents may satisfy legal demands but it does little to advance understanding of cause. This simplistic description of pilot performance problems is a poor guide to the prevention of similar accidents. Better schemes employed to classify factors thought to affect pilot behavior are of three general types. "Operational Tasks Executed Incorrect] includes failure to see and avoid aircraft, failure to maintain or the misjudgement of distance, altitude or speed; mismanagement of fuel, and failure to extend landing gear. "Psychological Failures Associated With Procedural, PerceptualMotor, and Decisional Errors"include workload problems, fatigue, stress, attentio and decision-making. The third scheme is based on"Factors Associated with The Conditions Surrounding The occurrence"such as phase of flight, type of mission, time of day, geographic location, weather conditions, total pilot flight time, and pilot certificates held.

These schemes help identify existing pilot performance problems but provide no direct guidance toward actions to be taken to prevent the problems. Descriptions of what happened must be followed by an understanding of why an error occur to identify preventative or corrective actions. A research structure based on th concepts of the human factors discipline provides an effective means of developin corrective actions. One mode ${ }^{8}$ attributes pilot performance problems to incong- 
ruities between the level of derands imposed by pilot tasks and the pilot's ability or motivation to perform them. Solutions to these problems require modification of task demands and/or pilot capabilities to eliminate physical, psychological, and physiological incongruities. Incongruities must be identified and one or more elements of an incongruity must be susceptible to change.

A design oriented approach using the body of knowledge of human factors affecting pilot performance has yielded a complex system model. In this model, developed for the FAA by Shelnutt, Childs, Prophet and Spears, ${ }^{7}$ three major components interact to produce pilot task demands. Three other major components interact to produce pilot capabilities. The task demands and pilot capabilities interact to produce either effective pilot performance or pilot performance problems. Figure 1. illustrates the model and shows design elements resulting from major design decisions that are associated with each model component.

Shelnutt et al analyzed a broad spectrum of information concerning pilot performance problems and associated human factors design issues using their model. Human factors design issues were formulated from inadequate information about system interrelationships and the effects of design alternatives on pilot performance. Thirty-five design issues were identified as requiring research to generate needed data required to support system design decisions. Figure 2 lists the design issues and shows their relationship to the design elements affecting the model components. Research into the use of part-task training and its enhancement of yisual simulation effectiveness provides data for design issues number 23 through 27 and 32 in Figure 2. This data probably contributes to all issues and elements of the training and proficiency assessment component of the system model in Figure 1. Some or all of the issues formulated for components affecting pilot capability will also be enlightened by part-task training research. Appendix $A$ is a compilation of references pertinent to a systematic, human factors, approach to evaluating pilot performance problems. 

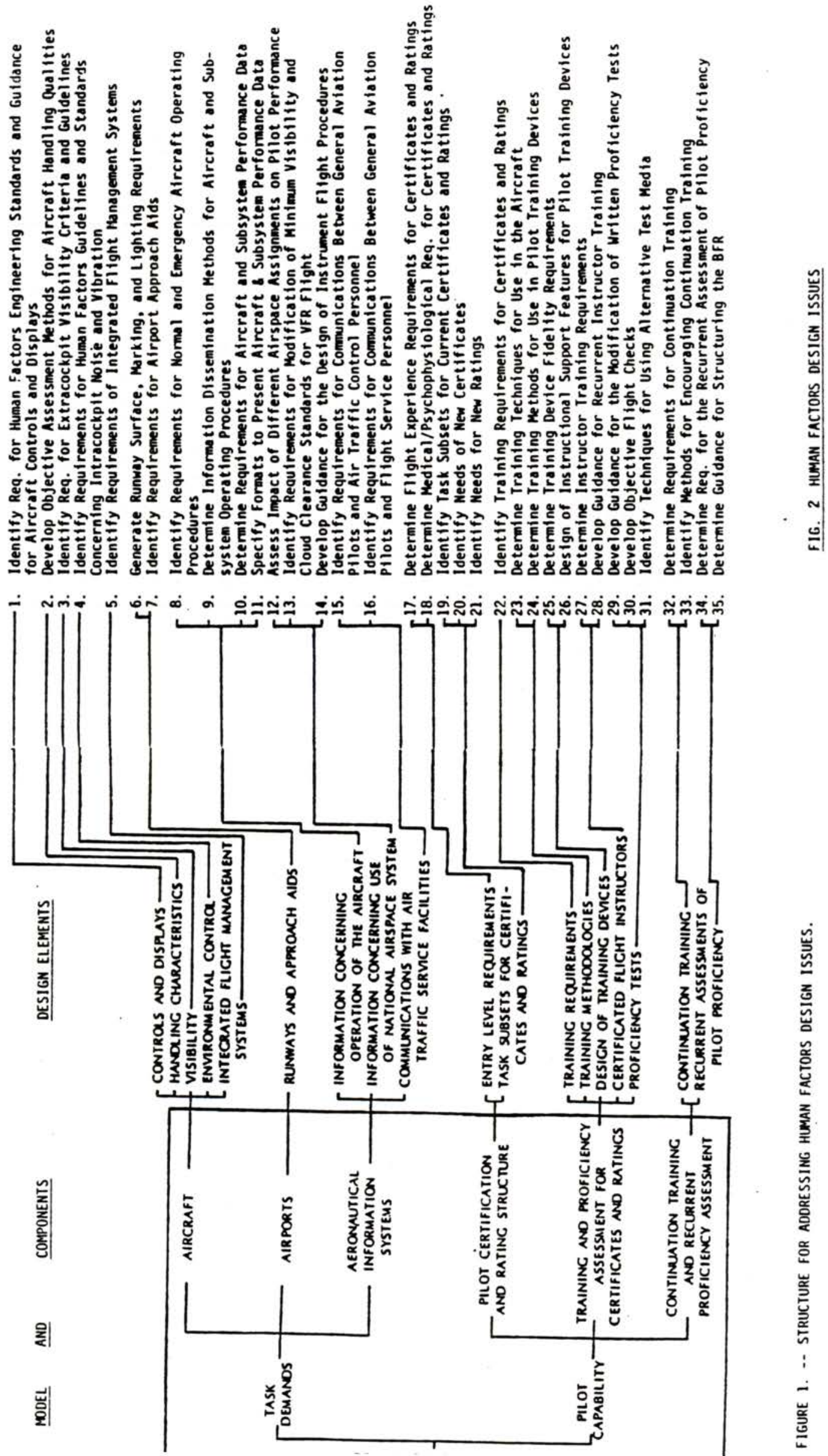


\section{Part-Task Training Theory}

Part-task training is practice on some set of components of a whole task before practice or performance of the whole task. Three general types of parttask manipulation schemes are identified in psychological literature. ${ }^{9} \underline{\text { Simpli- }^{-}}$ fication makes tasks easier by adjusting one or more characteristic of the task such as the turbulence level adjustments on flight simulators. Fractionation provides independent practice of subtasks that are executed simultaneously for the whole task such as pitch and roll control. Segmentation partitions a whole task either spatially or temporally such as takeoff, climb, cruise, descent, landing.

The schedule used to reintegrate the parts is a crucial variable. of the three schedules identified for fractionation ${ }^{10}$ and segmentation, pure-part training employs isolated practice of parts before whole task practice. In repetitive-part training one part is practiced, a second part is added and both are practiced together before another part is added. Progressive-part training uses isolated practice of new parts before they are added in repetitive fashion to parts that have been practiced. With simplification the number and size of step increases in difficulty could be varied.

Learning has been described as problem solving ${ }^{11}$ wherein knowledge of results is information about error that communicates the level of success at the problem solving task. Such information is actively processed generating hypothesis about how to improve performance. Any simplification condition that provides trainees with unambiguous error information should evoke early correct performance.

Current analysis of the process by which people approach learning tracking tasks indicates that it has three stages. ${ }^{12}$ First the trainee learns the proper direction of control movements to correct error conditions. Second, the trainee 
develops facility with timing of error correction response by learning to detect conditions which demand corrective input. Finally the trainee learns the proper magnitude of control movement for any given error condition. Improved early performance should result from simplification matching of the nature of error information to the trainee needs at each stage of learning. Segmentation practice on critical elements of a perceptual-motor task requiring performance over time or space can lead to early proficiency. This provides a larger amount of practice on the part of the task producing the strongest error information when the trainee needs it most.

\section{Part-Task Training Research}

Flying tasks can be described as continuous, perceptual-motor tasks characterized by complex multidimensional tracking. The search for new training techniques should follow suggestions from learning principles developed from research on perceptual-motor and tracking learning. However the organization, directions, and nature of motor behaviors studied in psychology laboratories have shortcomings in the application to complex training tasks. ${ }^{13}$ The principles need to be tested in a more systematic fashion on more complex and realistic tasks.

Performance differences during training do not imply similar differential learning in relation to the criterion or whole task. Applications research must be designed to evaluate the transfer-of-training (TOT) to substantiate the effectiveness of any specific technique. Appropriate TOT design must have multiple groups with at least one control group that is trained and tested entirely on the whole task. Each group should be trained for equivalent predetermined periods in only one condition prior to criterion testing. A balanced schedule of training periods employed in incremental transfer design ${ }^{15}$ is acceptable and can provide supplemental information.

Proper TOT design allows comparison of the transfer effects of prior exper- 
ience of a specific type on performance of the criterion task. Differential transfer estimates of the relative effects of equal amounts of experience with experimental and control conditions is also possible. Transfer theory and formulae ${ }^{16}$ show that transfer can be positive or negative but not greater than $100 \%$. Differential transfer can be greater than $100 \%$. This would indicate that training with the experimental condition is more efficient than the control condition for future performance in the criterion task. A positive differential transfer value below $100 \%$ indicates that the experimental condition is less efficient but does teach skills useful in the criterion task. Cost effective application of this experimental training technique could result if it was sufficiently less expensive than training in the control condition.

Besides early proficiency, an effective training strategy must facilitate maximum transfer by meeting three general conditions. ${ }^{17}$ First, any changes in response requirements resulting from the training technique must have perceptible changes in stimuli. Second, supplemental feedback should be provided when a task is low in intrinsic feedback. Third, to insure unambiguous error information, trainees should have a clear understanding of any differences between training and transfer tasks.

Wightman and Lintern ${ }^{18}$ have recently reviewed the literature and research in valid part-task training applicable to flight simulation. Most of the recent flight simulator work has been done by the Air Force, Navy, and the FAA. Most military work was done on advanced flight tasks such as carrier landings, dive bombing, and night flight in multi engine jet simulators. Most of the research involved the use of visual simulation systems added to an instrument cockpit simulator.

Recent fractionation research, some using visual flight simulation, has uncovered a strong interaction between task complexity and task organization. For tasks with high component complexity and high component interdependence, 
Fractional progressive part-task training has been less effective than whole task training. 19 Apparently the early proficiency in separate part practice does not transfer well to whole task performance. Since flight control tasks fit the character of these experiments, fractionation may not produce effective primary flight training.

However, fractional progressive part training for high component complexity and low component interaction has showed positive differential transfer greater than $100 \%$. This means the technique was found to be totally superior to whole task training. Other research in similar complex tracking task training has shown high positive differential transfer below $100 \%$

Fractionation by visual pretraining for teaching landings in an aircraft simulator with a visual display was tested. Passive-preprogrammed landings were viewed by the experimental group before simulator practice with no resultant improvement in their performance. 20 However, the long history of attempts to pretrain perceptual skill (perceptual pre-differentiation) indicate that positive transfer is very possible. Subjects need to actively seek distinguishing perceptual cues or make some decision about the yisual stimuli during pretraining. This was not done in the reported study.

Simplification is most effective for tracking tasks that are so difficult that learning is slowed since very little meaningful practice is achieved. Practice at easier tasks extends skills so the criterion task is no longer beyond trainee capability. Practice on easy tasks may establish a high performance standard as a goal that motivates the trainee after transfer to a more difficult task. Manipulations of rotation speed and control-display lag have shown differential transfer values from medium to high difficulty tasks of greater than 100\%. Manipulations of system order, gain, lag, forcing function, stability and damping ratio were found to generally not enhance training efficiency in 
flight tasks. Some general research that indicates the unlikely possibility of greater transfer from difficult-to-easier tasks ${ }^{18}$ have found possible correlation in present research.

The concept of augmented feedback is not strictly a simplification or even a part-task training technique. However, simulator studies have shown ${ }^{21}$ that it can speed acquisition if trainees are not permitted to develop dependencies on the supplementary cuing. An adaptive withdrawal technique to avoid such dependencies is suggested. Recent visual simulation experiments ${ }^{22}$ in a difficult ground reference maneuver task showed a strong effect of adaptive visual cuing. Differential transfer for augmented feedback training was positive and greater than $100 \%$.

With segmentation, difficult parts of a spatial or temporal task can be practiced intensively without spending time on easier or proficient parts. In three out of four recent experiments in segmented part task training of landing type maneuvers ${ }^{18}$ positive differential transfer was greater than $100 \%$. Visual simulations of dive bombing and carrier landings used a segmentation reintegration technique called backward chaining where the terminal segment was practiced first. Both pure-part and progressive-part reintegration (backwards) were successful. Only an experiment testing ground position freeze for enhancing carrier visual approach glidescope control produced less than $100 \%$ positive differential transfer. This is unexpected as mere isolation of a critical element for extended practice does not appear to be a strong technique. Even when the control group had more total training time, backward chaining produced superior results.

Wightman and Lintern ${ }^{18}$ discuss several concepts from perceptual-motor learning literature as hypotheses for the unusual success of backward chaining. In terminal tasks, such as landing an airplane, earlier segments may not be 
learned quickly because they are separated from the strong feedback of the final result. Activity between an action and the participant's knowledge of results (KR) of that action interferes with the progress of learning. Perhaps the association between the action and errors is obscured. In a backward progression, later task segments, once learned well, become the source of information feedback for earlier segments. Also, the post KR period apparently permits trainees to relate error information to earlier actions. Other activity such as prompt repetition of earlier task segments may interfere with this process. Prompt repetition of the same segment could enhance action-error correlation.

Also, in backward chaining, trainees do not have to cope with the ambiguities resulting from errors accumulated in prior segments. This follows the consistency in stimulus-response relationships concept. Trainees may learn more quickly simply because they experience a correct (errorless) performance more frequently than the whole task control group. Perhaps this results in learning to recognize the correct behavior more quickly.

The effects of individual subject differences has been a source of concern when creating and testing instructional treatments baseci on task manipulation. Measures of subject aptitude or abilities on the skills in question should contribute to the validity and knowledge gained in experiments. This question was addressed in one carrier-landing experiment previously discussed. ${ }^{18}$ A previously established yaluable measure of motor skill for research on human perceptualmotor tasks was used to calibrate the subject differences. This allowed tracking of high vs low motor skill subjects throughout the experiment. The results showed that high motor skill subjects performed best in all cases. However lag manipulations hurt low ability subjects and not hi ability subjects while segmentation variations helped the low much more than the hi. This aptitude 
by treatment interaction shows how transfer performance is influenced by both training technique employed and subject's ability. Appendix $B$ is a compilation of references pertinent to human factors part-task training applications to flight training.

5. Visual Simulation And Primary Flight Training.

To control an aircraft while visually scanning the airspace to navigate and avoid other traffic, a pilot must use an outside visual reference system. This reference system, mostly in the mind of the pilot, relates the aircraft attitude to the natural horizon. Learning and gaining confidence in using this outside visual reference system is difficult for the beginning pilot. There are many sources of distractions, such as noise, new surroundings, and new physical and visual perceptions associated with beginning flying experiences. These distractions are compounded by fluctuations in aircraft attitude induced by a tmospheric turbulence and untrained pilot control inputs. Because of these distractions, initial progress in learning to safely control an aircraft in flight is often slow. This discourages students and instructors and can incur significant costs in dollars, time, aircraft operating life, and air traffic control service.

Not only must pilots see and ayoid other aircraft in busy airport terminal areas, they must maneuver their aricraft with respect to airports and runways. This has to be done while at low altitudes and slow speeds where margins for error are reduced. Considerable attention is needed to hear and understand radio communications, and make radio transmissions, while maneuvering the aircraft and looking for traffic. Pilots must control the attitude and speed of the aircraft by outside visual references with only occasional reference to the instruments inside the cockpit.

Today most aircraft have a complete set of attitude control instruments 
in the cockpit and there is widespread use of cockpit instrument flight simulators. For most pilots there is strong emphasis on learning to control the aircraft solely by reference to cockpit instruments early in their training program. The cockpit instruments provide many exact points, marks, numbers and items of information about the aircraft's attitude and perfonmance. Outside visual references of aircraft attitude and performance are usually less discrete, more subtle, often combined, and appear to vary from aircraft to aircraft. Visval references also depend on the pilot's head and body position in the aircraft at any instant of time.

Beginning pilots often find it easier to deal with the discrete cockpit instrument indications than the seemingly nore combined outside visual references. There is an early and continued strong emphasis on learning to control the aircraft by reference to cockpit instruments. Many pilots develop the habit pattern of controlling their aircraft primarily by reference to cockpit instruments for all phases of flight. This incorrect aircraft control habit pattern often leads to poor or inadequate visual clearing to see and avoid other air traffic. Erratic airspeed and directional control, loss of navigation orientation awareness, unacceptable maneuvering with respect to the ground, and increased pilot fatigue also result. A thorough understanding of and confidence in the ability to control the aircraft by outside visual references is a necessary step toward becoming a safe and competent pilot.

Visual simulation pilot training devices designed according to the principles described earlier should be more cost effective than purely in flight training. A systems analysis of military, FAA, and collegiate flight training by McDenmott ${ }^{23}$ developed a list of 756 elements of flight training. Further refinement of elements for visual flight could determine visual flight training tasks that should be addressed with simulation. Effective training devices need 
not always reproduce the aircraft cockpit inflight conditions with hi-fidelity. Success occurs when performance in required tasks is learned in a manner that transfers to the aircraft at an overall cost savings. Oftentimes, as has been shown, part-task training techniques can produce both cost effective and totally superior training schemes. Until the recent research reviewed here, all aviation simulation strived for maximum fidelity to inflight conditions. Since present simulators emphasize instrument flight conditions, add on visual motion systems have not resulted in effective primary visual flight training. Recent FAA research ${ }^{24}$ has found that a $\$ 50,000$. price range generic multi-engine flight simulator was ineffective for basic multi-engine flight training. The device tested was a commercially available multi-engine instrument flight simulator with a rudimentary extra-cockpit visual display. Ten (10) hours of simulator instruction preceded eighteen (18) hours of flight training for two experimental groups. The simulator training produced no significant increase in performance either during flight training or on the FAA multi-engine class rating flight test. Simulator training did not even significantly enhance the instrument skills tested over the control group that just received the 18 hours of flight training.

This suggests the possible ineffectiveness of current general aviation simulation trends. Perhaps if the same effort were put into a multi-engine visual flight simulator with rudimentary instrument capabilities, more effective training would occur. It was noted in this study that multi-engine training is primarily visual-flight training. The simulator tested was little more effective than a static cockpit procedure training device that could probably be produced for one tenth the cost. High performance business aircraft training, the airlines, and the military make judicious use of these simple, but cost effective "mock up" training devices. 
The military has also used simple motion video recordings of the cockpit view of basic in-flight maneuvers for over a decade. Primary flight students view these real time motion recordings of maneuvers as part of their ground training. The military total systems approach also includes hi-fidelity instrument flight simulators but as yet no primary flight visual simulation. The USAF produces multi-engine ATP level pilots with less than 100 total hours of flight time.

A television video tape program using through-the-cockpit real time scenes enhanced with graphics and voice is in college use. ${ }^{25}$ This augmented feedback, pretraining fractionation, pure part reintegration, flight training instrument is now part of a pre-solo simulator course using instrument simulators. The program describes and shows how to control and coordinate the aircraft using only outside visual references. Qualitative response from students and flight instructors indicates favorable learning effectiveness when students transferred to aircraft. Computer interactive video driving of the tape was demonstrated but found ineffective due to the long video tape search tires. Computer interactive video disk technology as is being developed by the Jeppeson Sanderson Company holds great promise for increasing the training cost effectiveness of video recordings.

Computer generated video motion scenes appear to hold the greatest promise for flexibility and cost effectiveness in visual flight simulation training. The ATARI Air Combat Maneuvering (ACM) game has been proven to be a reliable, and effective gage of perceptual-motor skill applicable to flight. ${ }^{18}$ Several visual flight simulation programs are on the market for a variety of home computers.

The Flight Simulator II computer program marketed by SUb LOGIC Corporation can be purchased for under $\$ 50$. to run on several home computers. The video 
display is split between the windshield yiew and the instrument panel in forward view mode. Eight different directions of view can be selected independently for monitoring during flight. The video scene with a color monitor is realistic enough for useful flight simulation, having a scene projection rate of six (6) frames a second. ${ }^{26}$ An initial qualitative hands on assessment of the programs features and capabilities shows the Flight Simulator II has great potential. Sub LOGIC is working to replace the standard computer gaming joystick with aircraft like flight controls to seek FAA certification of the program as a flight simulator. With flight control inputs the program should be able to address all flight maneuvers required for the private pilot flight test.

Innovations in college level pilot training curriculums as have occurred at Daniel Webster College 27 benefit the most from effective training techniques. The program organization and control allows proper analysis of both where and when to use new techniques and their effectiveness. The large number student base also provides the test subjects needed to verify the effectiveness of new training techniques. Large, well organized, flight training programs are the best setting for the research needed to apply the human factors approach to solving pilot performance problems.

College faculty are professionals who can understand the human factors approach and create experiments to exploit it in developing educational techniques. Molenaar 28 has elegantly conceived the need and the potential of part-task visual simulation to enhance aviation education with his "single concept simulation" idea. Maximum effectiveness in this multi-faceted, interdisciplinary type of research requires experts from several areas of expertise. Hutchings 29 shows an excellent example of the enhanced results of professional collaboration between aviation faculty and faculty from other disciplines. All faculty, their students, the university and society benefit from this type 
of activity.

6. Conclusions

A systems analysis of human factors in pilot performance problems has generated a conceptual model for examining human factors interactions. Human factors design issues identified as needing research include many flight training issues. Human factors part-task training theory and methodology indicates that simulation can be very effective in addressing flight training issues.

Visual flight simulation shows new promise from new technology and recent theoretical and empirical investigations using a human factors approach to training. High fidelity simulation is not a mandatory requirement of an effective training device when theories of learning are applied. Part-task training capabilities have the potential to increase the effectiveness of a visual simulation training device beyond that of hi-fidelity whole task simulation. Part-task training schemes can best be implemented with computer video graphics displays.

College level education institutions have the best setting for the development of yisual flight pilot training devices. They have the existing program organization, test facilities, test subjects, and most of all, the college faculty research expertise. The depth and variety of academic and research disciplines available at the college level will be necessary to fully exploit the human factors approach to solving pilot performance problems.

The successful transfer of learning from simulation training techriques to pilot flight performance validates both the training device and the training technique. New training techniques should also be applied to actual inflight training when possible to enhance the overall training program effectiveness. The Cessna 152, Piper Tomahawk, and Beech Skipper are excellent flight simulators. 


\section{REFERENCES}

1. National Transportation Safety Board. Annual Review Of Aircraft Accident Data - U.S. General Aviation, Calendar Year 1977. Washington, D.C.: Author, Nov. 1978 (NTIS No. PB-29I 627)

2. Hopkins, C.0. Human Performance In Aviation Systems (ARL-77-14). Savoy, I1: University of ITlinois at Urbana - Champaign, (NTIS No. AD-A050-0781) July 1977.

3. Adams, J.A."Part Trainers", in Go Finch (Ed.). Educational and Training Media: A Symposium. Washington D.C., National Academy of Science - National Research Council Publication 789, 1960.

4. Wheaton, G.R., Rose, A.M. Fingeman, P.W., Korotkin, A.L., Holding, D.H. Evaluation of The Effectiveness Of Trainin Devices: Literature Review And re Iminary Model. Research Meroo. 76-6 Alexandria, VA: U.S. Anmy Research Institute For Behavioral And Social Sciences, April 1976.

5. Fastie W.H. "The IBM Personal Computer Takes Off", Creative Comouting magazine, Feb. 1983.

6. Arnoult, M.D., Stimulus Predifferentiation: "Sore Generalizations and Hypothes is" - Psychological Bulletin, 1957 54(4), 339-350

7. Shelnutt, J.B., Childs, J.M., Prophet, W.W., Spears, W.D. Human Factors Problems In General Aviation (FAA-CT-80-194). Washington, D.C. F.A.A., April 1980.

8. Zeller, A.F. Three Decades of USAF Efforts To Reduce Human Error Accidents 1947-1977. Paper presented at the 35th Specialists Aerospace Medical Panel Meeting of NATO Advisory Group for Aerospace Research and Devetopment, Paris, Nov. 1978.

9. Holding D.H. Principles of Training. Oxford: Pergamon Press 1965.

10. Naylor J.D. Perameters Affecting The Relative Efficiency of Part And Whole Training Methods. A Review of The Literature. Columbus OH: Ohio State University Research Foundation, Laboratory of Aviation Psychology, Tech. Rpt. NAVTRADEVCEN 950-1, 1962.

11. Adams, J.A. "Theoretical Issues For Knowledge Of Results." In G. Stelmatch (Ed.). Information Processing In Motor Control And Learning. New York: Academic Press, 1978.

12. Jaeger, R.J., Agarwal, G.C. Gottlieb, G.L. "Predictor Operator in Pursuit and Compensatory Tracking." Human Factors, 1980, 22, 497-506.

13. Singer, R.N. "Motor Skills And Learning Strategies." In H.F. O'Neil, Jr. (Ed). Learning Strategies. New York: Academic Press, 1978.

14. Childs, J.M., Spears, W.D., Prophet, W.W. Private Pilot Flight Skill Retention $8,16_{2}$ and 24 months following certification. DOT/FAA/CT-83/84 SEVILLE TR-83-17. 
15. Povermire, H.K., Roscoe, S.N., "Incremental Transfer Effectiveness of A Ground Based General Aviation Trainer." Human Factors, 1973, 15, 534-542.

16. Roscoe, S.N., Williges, B.H., "Measurement of Transfer Of Training." In Stanley N. Roscoe (Ed.), Aviation Psychology, Ames, I0: Iowa State University Press: Ames IO, 1980.

17. Wightman, D.C., Part-Task Training Strategies In Simulated Carrier Landing Final Approach Training. Human Factors Laboratory, Naval Training Equipment Center NAVTRAEQUIPCEN Tech. Rpt. IH-347, Nov., 1983.

18. Wightman, D.C., Lintern, G., Part-Task Training Of Tracking In Manual Control Naval Training Equipment Center NAVTRAEQIPCEN 81-C-0105-2, Sept. 83.

19. Naylor, J.C., Briggs, G.E., "Effects Of Task Complexity And Task Organization On The Relative Efficiency of Part And Whole Training Methods", Journal of Experimental Psychology, 1963, 65, 217-224.

20. Adams, J.A., Hufford, L.E., Effects of Programed Perceptual Training On The Learning of Contact Landing Skills. Port Washington, N.Y.: U.S. Naval Training Device Center Tach. RPT. NAVTRADEVCEN, 247-3, 1961.

21. Lintern, C., Roscoe, S.N., "Visual Cue Augmentation In Contact Flight Simulati In S.N. Roscoe, Aviation Psychology, Ames, 10: The Iowa State University Press, 1980.

22. Lintern, G., Thomley, K., Nelson, B., Roscoe, S.N. Content, Variety And Augmentation of Simulated Visual Scenes For Teaching Air-To-Ground Attack. Orlando, Fla: Naval Training Equipment Center, Tech. Rpt. NAVTRAEQUIPCEN 81-C-0105-3, 1984.

23. McDenmott, P.M., "Aviation Curriculum Design", University Aviation Association Fall Education Conference; 1983 Proceedings, Oct. 1983.

24. Childs, J.M., Lau, J.R., Spears, W.D., An Empirical Assessment of MultiEngine Flight Training DOT/FAA/CT-82/78, June 1982.

25. Kraemer, R.A., "Feature Article: Flight Training Through Computer Interactive Videotapes", University Aviation Association Newsletter, Apr. 1983.

26. Artwick, B.A., A2-FS2 Flight Simulator II Pilots Operating Handbook And Airplane Flight Manual, SubLOGIC Corp., Champaign, Ill., 1983.

27. Schultz, J.H., "An Integrated, Module Based, Flight Training Program", Univers. Aviation Association Fall Education Conference; 1983 Proceedings, Oct. 1983.

28. Molenaar, R.A. , "Curriculum Development/Integration: Single Concept Simulatic University Aviation Association Fall Education Conference; 1983 Proceedings, Oct. 1983.

29. Hutchings, B.L.,"Facilities Planning For Aviation Education", University Aviat Association Fall Education Conference, 1983 Proceedings, Oct. 1983 
APPENDIX A

Selected References On Human Factors And Pilot Performance

Aarons, R. N. Always leave yourself an out. Business and Commercial Aviation, 1973.

Adams, R. 1. An coerational evaluation of flight technical error (FM-RD-76-33). Washington, $\bar{D}$ : Federal Aviation Administration, July 1975. (NTIS No. AD-042 796)

Aircraft Onners and Pilots Association. The truth about general aviation. Washington, DC: Author, 1968.

Albrecht, A. P. A reply to the AlAA aircraft operations committee. Astronautics \& Aeronautics, $1980,18(2), 14 ; 45$.

Anderson, R. O. A new approach to the specification and evaluation of flying qualities (AFFDL-TR-69-120). Wright-Patterson AFB, OH: Aip Force Flight Dynamics Laboratory, 1970.

Aviation Advisory Commission. Ceneral aviation. Washington, $D$ : Author, May 1972. (NTIS No. PB-216 400)

Bain, D. The case against private aviation. New York: Cowles Book Company, Inc., 1969.

Beaty, D. The human factor in aircraft accidents. London: Secker and Warburg, Ltd., 1969.

Bergey, K. Ho Assessment of new technologies for general aviation aircraft (FMA-RD78-132). Washington, DC: Federal Aviation Administration, September 1978.

Bolz, E. H. \& Eisele, J. E. Ceneral aviation IFR operational problems (NASA-CR-159022). Washington, DC: National Ae ronautics and Space Administration, April 1979.

Boody, P. Riennial shell grme. Flying, 1980, 106(5), 79-90.

Booher, H. R. lob performance aids: Research and technology state-of -the-art (NPRDCTR-78-26). San Diego, CA: NaWy Personnel Research and Development Center, July 1978.

Booze, Jro, C. F. An epidemiologic investigation of occupation, age, and exposure in general aviation accidents (FAA-AM-77-10). Washington, $D C$ : Federal Aviation Administration, March 1977. (NTIS No. AD-A040 978)

Brantigan, J. When being on oxygen is not enough. The AOPA Pilot, 1974, 17(8), 38-40.

Bryan, C. L., \& Regan, J. 1. Training system design. In H. P. Van Cott \& R. C. Kincade (Eds.), Human engineering guide to equipment design (Rev. ed.). Washington, $D C$ : American Institutes for Research, 1972. 
Buckley, E. P., House, K., \& Rood, R. Development of a performance criterion for air traffic control personnel research through air iraffic control simulation (FAA-RD-78-71). Washington, DC: Federal Aviation Adrinistration, July 1978. (NTIS NO. AD-A058 082)

Bums, N. M., Chamber, R. M., \& Hendler, E. Unusual environments and human behavior. London: Free Press of Clencoe, 1963.

Caro, P. W. Aircraft simulators and pilot training. Human Factors, 1973, 15, 502-509.

Caro, P. W. Some current problems in simulator design, testing and use (HumRROPP-2 -77). Alexandria, VA: Human Resources Research Organization, March 1977.

Caro, P. Wo, Pohlmann, L. D., \& Isley, R. N. Development of simulator instructional feature design guides (Tech. Rep. TR 79-12). Pensacola, FL: Seville Research Corporation, October 1979.

Caro, P. Wo, Shelnutt, J. Bo, \& Spears, W. D. Utilization of aircrew training devices (Tech. Rep. TR 80-01). Pensacola, FL: Seville Research Corporation, February 1980.

Chapanis, A. Research techniques in human engineering. Baltimore, MD: The lohns Hopkins University Press, 1959.

Charles, 10 P. Instructor pilot's role in simulation training (Phase II) (NAVTRAEQUIPCEN-76-C-0034-1). Orlando, FL: Naval Training Equipment Center, August 1977.

Chien, R. T. On the Importance of program intelligence to advanced automation in flight aperations. Urbana, IL: University of lllinois at Urbana-Champaign, April 1977. (NTIS NO. AD-AO42 915)

Childs, 1. M. An analytic technique for identifying inflight performance criteria (WP-DAHC-19-77-C-0008). Fort Rucker, AL: Canyon Research Crolp, inc., Aril 1978.

Childs, 1. M., \& Halcomb, C. C. Effects of noise and response complexity won vigilance performance. Perceptual and Motor Skills, 1972, 35, 735-741.

Collins, R. L. A time for strength. Flying, 1980a, 106(1), 21.

Collins, R. L. Flaws in flying regs. Flying, 19806; 106(3), 32.

Collins, W. E., Hasbrook, A. Ho, Lennon, A. O., \& Cay, D. 1. Disorientation training in FM-certified flight and ground schools - a survey (FAA-AM 77-24). Washington, $\overline{D C}$ : Federal Aviation Administration, September 1977. (NTIS No. AD-A047 718)

Connor, T. M., \& Hamilton, C. W. Evaluation of safety programs with respect to the causes of general aviation accidents. Volume 1: Technical report. Columbus, $\mathrm{OH}$ : Battelle Columbus Laboratories, 1979 (Uraft). 
Cocper, C E, \& Maper, R. P. The use of pilot rating in the evaluation of aircraft handling qulities (NASA IN D-5153). Washington, DC: National Aeronaluics enc Space Administration, 1969.

Couch, E Vo, Hill, R M., Kolankiewicz, To, \& Skelton, Co Accident data systems studh requirements analysis for an FM accident data system (FM-NA-79-172). Washington, $D$ : Federal Aviation Administration, August 1979. (NTIS Nb. AD-A07! 611)

Crawford, M. P., Sollenberger, R. T., Ward, Lo B., Brown, C Wo, \& Chiselli, E. E Psy. chological research on coperational training in the continental aip forces (Rep. No. $\overline{16}$ ) Washington, $D$ : U.S. Covernment Printing Office, 1947.

Crook, W. C. Experimental assessment of ground trainers in seneral aviation pilot training (FM-ADS-67-5). Wastington, DC: Federal Aviation Administration, 1967. (NTI! No. AD-652 371)

Crosby, J. V., Pohlmann, Lo D, Lestowitz, B. \& Wag, W. L Evaluation of a low fidelit) simulator (LFS) for instrume training (AFHRL-TR-78-22). 8rooks AFB, TX: $A i$ Force Human Resources Laboratory, July 1978.

Curry, R. E. The analysis of the piloes' cognit/ve and decision processes (NASA-CR-145. 739). Washington, $D$ : National Neponautics and Space Administration, Nugust 1975 (NTIS No. N76-11722)

Czuchry, A J., Engel, H E., Dond, R, Baran, $H$ A, Dleterly, D, \& Creene, $R$ Mid-1980 dieital avionics information system conceptual desien confieuration (AFHRL $-T \overline{R-76-59}$ ) Brooks AFB, TX: Air Force Human Resources Laboratory, July 1976. (NTIS No AD-A032 137)

DeCreene, K. B. Systems psychology. New York: McCraw-Hill, 1970.

Del Balzo, 1. M. Air traffic control in the year 2000 (FM-NA-78-4). Washington, $D C$ Federal Aviation Administration, November 1977. (NTIS Nb. ND-A064 826)

Department of Defense. Human engineering design criteria for military systems, equipment and facilities (MIL-STD-1472B). Washington, DC: Nethor, 1974.

Department of the Air Force. AFSC design handbook $1-3$, human factors engineering. (Thir. Edition). Andrews AFB, $\bar{D}$ : Headquarters, Air Force Systems Command, Januar 1977.

Department of the Army. Human factors engineering design for Army materia (MIL-HDBK-759). Redstone Arsenal, AL: U.S. Army Missile Command, March 1975

Department of Transportation, \& National Aeronautics and Space Administration. Loin DOT-NUSA Civil Aviation Research and Development Policy Study Report (DO TST-10-4/NASA SP-265). Washington, $X$ : Author, March 1971a. 
Qxpartment of Transportation, \& National Neronactics and Space Administration. loint DOT-NASA civil aviation research and devicoment policy study - supporting papers (DOT TST-10-5ANSA SP-266). Washington, DC: Author, March 1971b.

Dille, J. Ro, \& Booze, C. F. The 1975 accident experience of cfvilian piloes with static physical defects (FM-AM-77-20). Washington, DC: Federal Aviation Adrninistration, August 1977. (NTIS No. AD-A045 429)

Dille, J. R., Mohler, S. R. Drug and toxic hazards in peneral oviation (FM-AM-68-16). Whington, $D$ : Federal Aviation Adrinistration, September 1968. (NTIS No. ND-686 670)

Dille; 1. R., Morris, E W. Herran factors in general aviation accidents. Washington, DC: Federal Aviation Agency, July 1966. (NTIS No. ND-640 971)

Dosch, V. F. Federal Aviation Administration research and development programs for aiports. Proceedings of the First FM Ceneral Aviation Research and Develogment Conference. Washington, DC: Federal Aviation Administration, August 1977.

Dosch, V. F. Marking and lighting of usaved nowovs (NA-78-34-LR). Nelantic City, NI: National Aviation Facilities Experimental Center, May 1978.

Dosch, V. F. Low-cost visual approsch slope indicators (NA-78-52-LR). Atlantic City, Nf: National Aviation Facilities Experimental Center, Februry 1979.

Eddowes, Eo, McRee, P., Matheny, Wo, Crouder, N. Preliminary coerational evaluation of an audiovisusl instrument training device (AFHRL-TR-75-49). Brooks AFB, TX: Air Force Human Resources Laboratory, July 1975. (NTIS Nb. AD-1016 487)

Edrronds, 1. D., Pursel, R. H, \& Callagher, 1. A flight imvertigation of system accuracies and cperational capabilities of a general aviation area novigation system (FAA-RD-77-43). Washington, DC: Federal Aviation Administration, June 1977. (NTIS NO. AD-AO42 B46)

Edwards, C. As analysis of aviation safety information (FM-MS-76-1). Washington, $D C$ : Federal Aviation Administration, November 1975. (NTIS No. AD-A020 549)

Egsspuchler, 1. J. The accident record in terms of the pilot. Proceedings of the Princeton University Conference on Ceneral Aviation Safefy (FMA-RD-74-154). Washington, $D$ : Federal Aviation Adrinistration, Ctober 9974. (NTIS Nb. ND-A0O3 124)

Egispuehier, J. J., \& Weislogel, C S Study to determine the flight profile and mission of the certifled private pilot (FM-DS-68-15). Washington, $\mathcal{C}$ : Federal Aviation Administration, July 1968 (NTIS No. ND-675 818)

Eldredge, D, Coldburg, B., Crimbring, W. An evaluation of modified RNAV terminal procedures using a single-way point RNAV system (FMA-RD-78-27). Washington, $D$ : Federal Aviation Administration, April 1978. (NTIS Nb. AD-A054510) 
Ellis, D R. Flying qualities of small seneral aviation aiplanes - Part 2 (FM-RD70-65). Wishington, $X:$ Federal Aviation Administration, pril 1970 (NTIS No. AD-715 582)

Ellis, D Ro Flying quallties of small eeneral aviation aiplenes - Part \& (FM-RD-71118). Whington, $\mathcal{C}$ : Federal Aviation Administration, December 1971. (NTIS No AD-739 880)

Ellis, D R. Ceneral aviation handling qulities research. Proceedings of the Princetor University Conference on Ceneral Aviation Safety (FM-RD-74-154). Federal Aviation Administration, October 1974. (NTIS NO. ND-A0O3 124)

Ellis, D. Ro, \& Criffith, C. L. A study of koneitudinal controllabllity and stabilit) requirements for small seneral aviation airplanes (FM-RD-78-113). Washington, $D C$ Federal Aviation Administration, August 1978. (NTIS No. ND-ND60 467)

Ellis, D R., \& Steinberger, 1. A study of lightolane stall moidance and suppressior (FAA-RD-77-25). Whington, DC: Federal Aviation Administration, February 1977 (NTIS NO. ND-NO39 223)

Elson, B. M. Navy expands simpler cockpit diplays. Aviation Week \& Space Tectrology $1977,107(2), 59-64$.

Eschenbrenner, A Effects of intemittant noise on the perfomance of a complex psycho. motor task. Human Factors, 1971, 13, 59-63.

Federal Aviation Administration. Flight test gulde, private Dibo, airplane (revised) Washington, $D C$ : Nuthor, 1975a.

Federal Aviation Administration. The National Aviation System Plan. Auttor, March 1975b.

Federal Aviation Administration. United States randards for terminal instrument pro. cedures (8260.38). Ashington, DC: Author, July 1976.

Federal Aviation Administration. Aimman's information mamual, Part i. Washington, $\propto$ Aertor, July $1977 a$.

Federal Aviation Administration. Aviation instructor's handbook (AC 60-14). Wastington DC: Nurtor, 1977b.

Federal Aviation Administration. Systems Research and Development Service, Drogres report (FM-RD-78-90). Washington, $D$ : Nethor, August 1978a. (NTIS NK

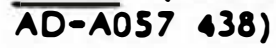

Federal Aviation Administration. Helicopter Coerations Develooment Plan (FAA-RD 78-101). Washington, $D$ : Nuthor, September 1978b. 
Federal Aviation Administration. Ceneral aviation pibt stall awareness training syllabus. Washington, DC: Author, February 1979a.

Federal Aviation Administration. Pilot proficiency award program (AC 61-91). Washington, DC: Author, May 19796.

Federal Aviation Administration. Helicapter air traffic control aperations (FM-RD78-150). Washington, $D C$ : Nuthor, May 1979c.

Federal Aviation Administration. Cuide to Federal Aviation Administration publications (FNA-APA-PC-2). Washington, DC: Author, June 1979d.

Federal Aviation Administration. Federal Aviation Administration aviation forecasts: Fiscal years 1980-1991. Washington, DC: Nuthor, September 1979e.

Federal Aviation Administration. Flight training hanobook (AC 61-21A). Washington, $D$ : Aurthor, 1980.

Fink, D. E. Digital information system tested. Aviation Week \& Space Technology, 1978, 108(17), $109-116$

Fink, D. E. CAMA expects 1981 sales of 53 billion. Aviation Week \& Space Technology, $1980,192(5), 64-66$.

Finnegan, 1. P. Evaluation of the transfer and cost effectiveness of a complex computerassisted flight procedure trainep (ARL-77-7). Savoy, IL: University of Illinois at Uriona-Champaign, June 1977. (NTIS Nb. AD-A05, 413)

Fitts, P. M., \& lones, R. E. Psychological aspects of instrument display--1. Analysis of 270 'pilot-error" experiences in reading and interpreting aircraft instrements (Report No. TSEAA-694-12A). Wright-Patterson AFB, OH: Aero Medical Laboratories, October 1947.

Foley, 1. P. Instructional materials for improved job performance (AFHRL-TK-78-99). Brooks AFB, TX: Air Force Human Resources Laboratory, January 1979.

Forrest, F. C Develap an objective flight test for the cerrification of a private pilot (DS-70-17). Washington, $D$ : Federal Aviation Administration, May 1970.

Forsyth, D. L., \& Shaughnessy, J. D. Single pilot IFR cperating problems determined from accident data analysis (NASA-TM-78-773). Washington, $D$ : National Aeronautics and Space Administration, September 1978.

Fraser, R. C. Institutional factors in civil aviation (DOT-05-00083). Washington, $D$ : Department of Transportation, January 1971.

Carvey, w. Training and proficiency in the classroom. The AOPA Pilot, 1974, 17(10), 34-35. 
Ceneral Accounting Office. Improved controls needed over private pilot licensing (RED76-65). Washingeon, $D C$ A Author, February 1976.

Ceneral Accounting Office. Aircraft delays at major U.S. aiports can be reduced (CED-79-102). Washington, DC: Author, September 1979a.

Ceneral Accounting Office. FM's program to automate flight service stations: Status and needs (PSAD-80-1). Washington, DC: Author, Oztober 197\%t.

Ceneral Accounting Office. How to improve the Federal Aviation Administration's abilizy to deal with safety hazards (CED-80-66). Washington, $X$ : Nuthor, February 1980.

Ceneral Aviation Manufacturers Association. Specifications for the pllot's coerating handtook. Washington, DC: National Standards Association, 1975.

Cerathewohi, S 1. Psychaotysiological effeets of aging - developing a functional age index for pilots: 1. A sumey of the pertinent literature. Washington, DC: Federal Aviation Administration, April 9977. (NTIS No. AD-A040 322)

Cerathenohl, So 1. Psychaohysiological effects of aging - develooing a functional age index for pilots: II. Taxonomy of psycho ical factors (FM-AM-78-16). Washington, DC: Federal Aviation Administration, pril 1978a. (NTIS Nb. ND.A054 356)

Cerathewohl, S J. Psychootysiological effects of aging - developing a functional age index for pilots: III. Measurement of pllot performance (FM-AM-78-27). Washington, DC: Federal Aviation Administration, August 1978b. (NTIS No. NO-A062 501)

Coff, R. C. Highlights 1979: Atmospheric environment. Astronautics \& Aeronauties, $1979,17(2), 36-38$

Coomey, A. The human factor in aircraft accidents-investigation of background factors of pilot error accidents (FPRC/Memo-224). London, England: Flying Personnel Research Committee, May 1965. (NTIS No. N66-28888)

Corill, R. B, \& Snyder, F. W. Preliminary study of aircrew tolerance to low-frequency veptical vibration (D3-1189). Seattle, WA: Boeing Corporation, July 1957.

Creer, P. E., Hanking, 1. R. Application of AIDS to the A-7E and a projected furure tactical aireraft (NACC-78032-060). Waminster, PA: Naval Air Development Center, December 1977. (NTIS No. AD-A053 775)

Crosslight, J., Fletcher, $H_{0}$ J., Masterton, Ro, \& Brucehagen, R. Monocular vision and landing performance in general aviation pilots: Cycloos revisised. Human Facsors, 1979, 20, 27-33. 
Hasbrook, A. Ho, Rasmussen, P. C, \& Willis, D. $M$. Pllot performance and heart rate during in-flight use of a compact instnoment display (FA-AM-75-12). Washington, DC: Federal Aviation Administration, November 9975. (NTIS Nb. ND-A021 519)

Helms, J. L. Ceneral aviation: The coportunity and the challenge. ICAO Bulletin, 1975, 30(9), $12-15$.

Henry, T. Fo, \& Froehlich, M. The Beneral aviation industry: An overview (FM-AVP75-4). Washington, $D$ : Federal Aviation Administration, July 1975. (NTIS No. AD-A015 871)

Hess, R. A Prediction of pilot apinion ratings using an optimal pilot model. Human Factors, 1977, 19, 459-476.

Hinton, D A, \& Shaughnessy, 1. D Adaption of the time line analysis program to single pibe instrument flight research (NASA-TM-78748). Washington, DC: National Aeronautics and Space Adrinistration, August 1978.

Hoekstra, Ho D, \& Huang, S. Safety in general aviation. Arlington, VA: Flight Safety Foundation, 1971.

Hof fman, W. C., \& Hollister, W. M. Ceneral aviation pilot stall awareness training study (FAA-RD-77-26). Washington, $D C:$ Federal Aviation Adninist ration, September 1976. (NTIS NO. AD-AO41 310)

Hollister, W. M., Lo pointe, $\uparrow$, Oman, C. M., \& Tole, J. R. Ident lfying and determining skill degradations of private and commercial pilots (FM-RD-73-91). Washington, DC: Federal Aviation Adrinist ration, September 1973.

Hookins, C. Q Human performance in aviation systems (ARL-77-14). Savoy, IL: University of Illinois at Urbana-Champaign, July 1977. (NTIS Nb. AD-A050 0;8)

Hopkins, V. D. Human factors in the ground control of aircraft (ACARD-AC-142-70). Neuilly sur Seine, France: North Atlantic Treaty Organization, Advisory Croup for Aerospace Research and Development, toril 1970. (NTIS No. AD-706 550)

Homick, R. J., \& Lefritz, No M. A study and review of human response to prolonged random vibration. Human Factors, 1966, 6, 481-492.

Hudock, P. Fo, \& Hubek, R. P. The coerational proflle and mission of the certified non instrument rated commercial pilot (FAA-RD-70-50). Washington, $D$ : Federal Aviation Administ ration, July 1970.

Hurst, R. (Ed.). Pilot error. London: Granada Publishing, Lid., 1976.

Ince, F., Williges, R. C., \& Roscoe, S. N. Aircraft simulator motion and the order of merit of flight attitude and steering 8uidance displays. Human Factors, 1975, 17, $388-400$. 
Jacobs, R. S., \& Roscoe, S. No Simulator coclopit motion and the transfer of flight training. Proceedings of the 19th Annual Meeting of the Human Factors Society. Santa Monica, CA: Human Factors Society, Cctober 1975.

Jensen, R. So Pilot judgment: Tralning and evaluation. Eleventh NTEC/Industry Conference Proceedings. Orlando, FL: Naval Training Equipment Center, November 1978.

Jensen, R. So Prediction and ouickenine in Derspective flight disolays for curved landing approaches (Doctoral dissertation, University of Illinois a Urbana-Champaign). Ann Arbor, MI: University Microfilms International, May 1979. (University Microfilms No. $80-04198)$

Jensen, R. S. Uses of a visual landing system in primary flight training. Proceedings of the Human Factors Society - 17th Annual Meeting, 1973.

lensen, R. S. \& Benel, R. ^ Judgment evaluation and instruction in civil pilot training (FM-RD-78-24). Washington, $D$ : Federal Aviaton Administration, December 1977. (NTIS No. AD-AO57 440)

lensen, $R_{0} S_{0}, \&$ Roscoe, $S_{0} N_{0}$ Fllght tests of pilotage eprop in area navigation with vertical guidance (FM-RD-72-126). Washington, DC: Federal Aviation Administration, August 1973. (NTIS No. ND-772 463)

lensen, R. So, \& Roscoe, S. $N_{\text {. }}$ Flight tests of pilotage epror in area navigation with vertical guidance: Effects of navigational procedural complexity (FM-RD-74-148). Washington, $D$ : Federal Aviaton Administration, August 1974. (NTIS NO. ND-A0O3 796)

Jotnson, So L., \& Roscoe, S. N. What moves, the airplane or the morld? Hurran Factors, $1972,14,103-125$.

Kirktam, W. Ro, Collins, W. Eo, Crape, P. Mo, Simpson, J. Mo, \& Wallace, T. F. Soatial disorientation in general aviation accidents (FM-AM-78-13). Washington, $D$ : Federal Aviation Administration, March 1978. (NTIS NO. ND-AO53 230)

Kiteley, C. W. Ceneral Aviation and community develapment. Aviation Research lournal, 1976, 1, 59-62.

Kiteley, C. W., \& Harris, R. L. Instructor and student pilot's subjective evaluation of a general aviation simulator with a terrain visual system (NNSA-TM-78698). Washington, DC: National Aeronautics and Space Administration, April 1978. (NTIS No. N78-23746)

Klass, P. I. Decision computers studied for ATC. Aviation Week \& Soace Technology, 1979, $111(21), 37-39$

Kleinman, D. Lo, Baron, So, \& Levison, W. Ho An cotimal control model of human response, Parts 1 and II. Autornatica, 1970, 6, 357-383. 
Koonce, J. M. Effects of ground-based aircraft simulator motion conditions upon prediction of pilot proficiency (TR ARL-74-5). Savoy, IL: University of Illinois at Urbana-Champaign, 1974.

Kowalsky, No B., Masters, Ro L., Stone, R. B., Babcock, C. L, \& Rypka, E. W. An analysis of pilot error-related aircraft accidents (NASA CR-2444). Washington, DC: National Ae ronautics and Space Administ ration, June 1974.

Kryter, K. The effects of noise on man. New York: Academic Press, 1970.

Lacefield, D. J., Roberts, P. A., \& Blossom, C. W. Agricultural aviation versus ocher general aviation: Toxicological findings in fatal accidents (FAA-AM-78-31). Washington, $D C$ : Federal Aviation Administration, September 1978. (NTIS No. $A D-A 060$ 110)

La Foy, A. B. Ceneral aviation, selected references (DOT-OST-LIB-10). Washington, DC: U.S. Department of Transportation, June 1977.

Lanier, H. M., \& Butler, E. D. An experimental assessment of ground pilot trainers in general aviation (FAA-ADS-64). Washington, $D$ : Federal Aviation Administration, 1966.

Lawton, Ro. So, \& Livack, G. So Proceedings of the AOPA Air Safety Foundation and Ceneral Aviation Manufacturers Association general aviation safety workshop. Workshop conducted at the Ohio State University, Columbus, OH, 1979.

Lederer, J. Human factors and pilot epror. Arlington, VA: Flight Safety foundation, 1973.

Lewis, M. F. \& Mertens, H. W. Pilot performance during simulated approaches and landings made with various computer-generated glide path indicators (FAA-AM-79-4). Washington, DC: Federal Aviation Administration, September 1978. (NTIS No. AD-A066 220)

Lintern, G. Transfer of landing skill after training with supplementary visual cues. Proceedings of the 23rd Annual Meeting of the Human Factors Society. Santa Monica, CA: Human Factors Society, October 1979.

Lintem, C., \& Roscoe, S. N. Transfer of landing skill after training with supplemental visual cues. Proceedings of the 6th Symposium on Psychology in the Department of Defense. Colorado Springs, CO: U.S. Air Force Academy, 1978.

Loftus, C. R., Dauk, V. J., \& Williams D. Short-tem memory factors in ground cont roller/ pilot communication. Human Factors, 1979, 21, 169-182.

Lucaccini, L. (Ed.). Aircrew emergency decision training: A conference report. Wbodland Hills, CA: Perceptronics, November $28-30,1978$.

Malo, E. 1. Area navigation for general aviation implementation. Proceedings of the First FAA Ceneral Aviation Research and Development Conference. Washington, $D$ : Aviation Administration, August 1977. 
Matheny, W. C. Training research program and plans: Advanced simulation in undergraduate pilor training (AFHRL-TR-75-26(11). Brooks AFB, TX: Air force Human Resources Laboratory, June 1975.

McColbugh, 1. B A design perspective on new technologies for general aviation. Aeronautics \& Astronautics, 1979, $17(9), 48-53$.

McConkey, E. D., \& Halverson, $A$ C. RNAV roure design--Terminal area design procedures and transition area design guidelines (FM-RD-78-61). Washington, $D C$ : Federal Aviation Administration, January 1978. (NTIS No. AD-A062 053)

McCormick, E. 1. Human factors in emgineering and design. New York: McCraw-Hill, 1976.

McCourt, F. P., \& Hewin, L. M. A study of key problems in general aviation safety. Washington, $D$ : Aircraft Onners and Pilots Association Air Safety Foundation, March 1979.

McFarland, R. A. Huran factors in air transportation design. New York: McCraw-Hill, 1946.

McFarland, R. A Human factors in air transportation. New York: McCraw-Hill, 1953.

Meister, D Human factors: Theory and practice. New York: Wiley-Interscience, 1971.

Meister, $D$ Development and use of human performance data for design. In $K$. D. Cross \& 1. 1. McCrath (Eds.), Crew system design. Santa Barbara, CA: Anacopa Sciences, Inc., July 1973.

Meister, D, \& Rabideau, C F. Human factors evaluation in system development. New York: John Wiley \& Sons, 1965.

Mertens, $H_{6} W_{0}$ Comparison of the visual perception of a runway model in pilots and nonpilots during simulated night landing approaches (FM-AM-78-15). Washington, $D$ : Federal Aviation Administration, March 1978.

Meyer, R. P., Laveson, 1. 1., Pape, C. Lo, \& Edwards, B. 1. Development and application of a task taxonomy for tactical flying (AFHRL-TR-78-42[1]). Brooks AFB, TX: Air Force Human Resources Laboratory, September 1978.

Miller, R. B. Handbook on training and training equipment design (TR-53-136). Wright Patterson AFB, OH: Wright Air Develapment Center, June 1953.

Miller, R. B. Psychological considerations in the design of training equipment (TR 54-563). Wright-Patterson AFB, OH: Wright Air Develooment Center, December 1954.

Miller, R. M., Swink, J. R., \& McKenzle, J. F., JP. Instructional systems develooment (ISD) in Air Force flying training (AFHRL-TR-78-59). Brooks AFB, TX: Air force Human Resources Laboratory, December 1978. 
Mohler, S. R. Recent findings on impairment of aimanship by alcohol (FMA-AM 66-28). Washington, $D$ : Federal Aviation Agency, September 1966. (NTIS Nb. AD-644 119)

Mohler, So R. Medical facts for pilots. Proceedings of the First FMA Ceneral Aviation Research and Developmeme Conference. Washington, DC: Federal Aviation Administ ration, August 1977.

Montemerlo, M. D. The instructional system development manual: Tool or tyrant. Paper presented at the meeting of the American Psyctologlcal Association, New York, September 1979.

Montemerlo, M. D, \& Tennyson, M. E. Instructional systems development: Conceptual analysis and comprehenslve bibliography (NAVTRAEQUIRCEN IH-257). Orlando, FL: Naval Training Equipment Center, February 1976.

Mozell, M. M., \& Mnite, D. C. Behavioral effects of whole body vibration. loumal of Aviation Medicine, 1958, 29, 716-724.

Munley, F. Commeter airline safety: An analysis of accident records and the role of federal regulations. Washington, $D C$ : Aviation Consumer Action Project, August 1976.

National Aeronautics and Soace Adininistration. Aircraft safety and operating problems (NASA-SP-416). Washington, $D$ : Author, 1976.

National Aeronautics and Space Aministration. Third quarterly reDOrt (NASA-TM-X-3546).

NASA Aviation Safety Reporting System: Washington, $D$ : Author, May 1977a.

National Aeronautics and Space Administration. NASA Aviation Safety Reporting System: Fourth quarterly report (NASA-TM-78433). Washington, DC: Nuthor, October 1977b.

National Aeronautics and Space Administration. NASA Aviation Safety Reporting System: Fifth quarterly report (NASA-TM-78476). Washington, $D$ : Author, April 1978a.

National Aeronautics and Space Administration. NASA Aviation Safety Reporting System: Sixth quarterly report (NASA-TM-78511). Washington, DC: Nuthor, July 1978b.

National Aeronautics and Space Administration. NASA Aviation Safety Reporting System: Seventh quarterly report (NASA-TM-78528). Washington, DC: Author, August 1978c.

National Aeronautics and Space Administration. NASA Aviation Safety Reporting System: Eighth quarterly report (NASA-TM-78540). Washington, DC: Author, October 1978d.

Vational Aeronautics and Space Administration. NASA Aviation Safety Reporting System: Ninth quarterly report (NASA-TM -78608). Washington, DC: Awthor, June 1979.

Jat ional Association of Flight Instructors. Cuidelines for the conduct of Biennial Flight Reviews. Columbus, OH: Author, 1976.

lational Transportation Safety Board. Aircraft design-induced pilot error. Washington, DC: Author, July 1967. (NTIS No. PB-175 629) 
National Transportation Safety Board. Midair collisions in U.S. civil aviation - 1968. Washington, $D$ : Nuthor, July 1969.

National Transportation Safety Board. Study of lessons to be leamed from accidents attributed to turbulence (NTSB-MS-71-1). Washington, DC: Nerthor, December 1971.

National Transportation Safety Board. Carburetor ice in general aviation (NTSB-MS72-1). Washington, $D$ : Author, January 1972a. (NTIS No. PB-208 463)

National Transportation Safety Board. Emergency landing techniques in small fixed-wing aircraft (NTSB-AAS-72-3). Washington, $D$ : Author, Apil 1972b. (NTIS No. $\overline{P B-209}$ 836)

National Transportation Safety Board. Midair collisions in U.S. civil aviation, 1969 1970 (NTSB-AAS-72-6). Washington, DC: Author, June 1972c. (NTIS No. PB-211 $\overline{906)}$

National Transportation Safety Board. Special study - general aviation stall spin accidents, $1967-1969$ (NTSB-MS-72-8). Washington, DC: Nuthor, Septernber 1972d. (NTIS No. PB-213 614)

National Transportation Safety Board. Air taxi safety study (NTSB-AAS-72-9). Washington, DC: Nuthor, September 1972e.

National Transportation Safety Board. Special study - accidents imolving engine failure/ malfunction: U.S. general aviation, 1965-1969 (NTSB-ASS-72-10). Washington, DC: Aluhor, November, $1972 f$.

National Transportation Safety Board. Special study - report on approach and landing accident prevention forum (NTSB-A AS-73-2). Washington, DC: Aurthor, September 1973.

National Transportation Safety Board. Soecial study - U.S. general aviation accidents involving fuel starve..on, 1970-1972 (NTSB-AAS-74-1). Washington, DC: Author, April 1974a. (NTIS No. PB-231 853)

National Transportation Safety Board. Special study of fatal, meather-involved, general aviation accidents (NTSB-MS-74-2). Washington, DC: Nuthor, Nugust 19746.

National Transportation Safety Board. Special study - U.S. general aviation takeoff accidents: The role of preflight preparation (NTSB-AAS-76-2). Washington, $D$ : Aurhor, March 19763.

National Transportation Safety Board. Special study - nonfatal, weather involved general aviation accidents (NTSB-AAS-76-3). Washington, $D$ : Author, May 1976b.

National Transportation Safety Board. Flightcrew coordination procedures in air carrier instrument landing system approach accidents (NTSB-AAS-76-5). Washington, DC: Author, August 1976c. (NTIS No. PB-258 720) 
National Transportation Safety Board. Annual review of aircraft accident data - U.S. general aviation, calendar year 1977. Washington, DC: Nuthor, Noveriber 1978. (NTIS No. PB-291 627)

National Transpoptation Safety Board. Special study - single-engine, fixed-wing Beneral aviation accidents, 1972-1976 (NTSB-MSS-79-1). Washington, DC: Nuthor, May 1979a.

National Transportation Safety Board. Soecial study - llght twin-engine aircraft accidents following engine failures, 1972-1976 (NTSB-MS-79-2). Washington, $D$ : Author, December 1979b.

Olcott, 1. W. What's wrong with flight training. Flying, 1977, 109(4), 74-75.

Onstott, E. D. Prediction and evaluation of flying qualities in turbulence. Proceedings of the Eighth Annual Conference on Manual Control. Am Arbor, MI: University of Michigan, 1972.

Ontiveros, R. Effectiveness of a pilot ground trainer as a part-task instrument flight rules flight-checking device: Stage I (FAA-RD-7S-36). Washington, DC: Federal Aviation Administration, September 1975. (NTIS Nb. AD-A015 722)

Ontiveros, R. Effectiveness of a pilot ground trainer as a part-task instrument flight rules flight checking device: Stage II (FM-RD-76-72). Washington, DC: Federal Aviation Administration, June 1976. (NTIS NO. AD-A026 754)

Ontiveros, R. Jo, Spangler, R. M., \& Sulzer, R. Lo Ceneral aviation (FAR23) cockpit standardization analysis (FM-RD-77-192). Washington, $D$ : Federal Aviation Adrinistration, March 1978. (NTIS No. AD-A052 803)

Orlansky, J., \& String. J. Cost effectiveness of flight simulators for military training. Volume 1: Use and effectiveness of flight simulators (IDA Paper P-1275). Arlington, VA: Institute of Defense Analysis, August 1977.

Parker, 1. Fo, \& West, V. R. Bionst ronautics data book (NASA-SP-3006). Washington, DC: Nat ional Aeronautics and Space Administration, 1973.

Parker, L. C. Ceneral aviation air traffic pattem safety analysis (NASA-TM-X-69455). Washington, $\overline{D C}$ National Aeronautics and Space Administration, July 1973.

Pazera, E. Preliminary evaluation of user terminals for an automated pilot briefing system (FM-RD-76-118). Washington, $D$ : Federal Aviation Administration, August 1976. (NTIS NO. AD-A030 660)

Poritzky, S. B. Meeting general aviation needs for the future in the evolving ATD systems. Proceedings of the First FAA Ceneral Aviation Research and Develooment Conference. Washington, $D$ : Federal Aviation Administration, August 1977.

Post, T. 1. The develooment of human factors research objectives for civil aviation. Arlington, VA: Serendipity, Inc., June 1970. (NTIS No. N73-14015) 
Povermire, Ho Ko, \& Roscoe, S. N. An evaluation of ground-based flight trainers in rout ine primary flight training. Human Factors, 1971, 13, 109-116.

Prophet, W. W. Long-term retention of flying skills: A review of the literature (HumRRO-FR-EO(P)-76-35). Alexandria, VA: Hum Resources Research Organization, October $1976 a$.

Prophet, W. W. Long-term retention of flying skills: An annotated bibliography (HumRRO$F R-E D(P)-76-36)$. Alexandria, VA: Human Resources Research Organization, October $1976 b$.

Prophet, W. W. U.S. NaWy fleet aviation training program development (NAVTRAEQUIPCEN77-C-0009-1). Orlando, FL: Naval Training Equipment Center, March 1978.

Prophet, W. W., \& Boyd, $H \wedge A$ Device-task fidelity and transfer of training: Aircraft cockpit procedures training (Tech. Rep. 70-10). Alexandria, VA: Human Resources Research Organization, July 1970.

Prophet, W. W., \& Jolley, Q B. Evaluation of the integrated contact-instrument concept for Army fixed wing flight instruction (Tech. Rep. 69-26). Alexandria, VA: Human Resources Research Organization, December 1969. (NTIS Nb. AD-703 161)

Prophet, W. W., Shelnutt, 1. B, \& Spears, W. D Future research plans: A report of the simulator training requirements and effectiveness study (STRES) (Tech. Rep. TR 80-02). Pensacola, FL: Seville Research Corporation, February 1980.

Pyle, J. T. A general aviation user response to airman R\&D programs. Proceedings of the First FM Ceneral Aviation Research and Develapment Conference. Washington, DC: Federal Aviation Administration, Nugust 1977.

Richardson, D W. Highlights 1979: Aircraft cperations. Astronautics \& Aeronautics, $1979, \underline{17}(2), 18-20$.

Riddle, J. I. Effectiveness of ground pilot trainers and training for pilots judgment improvement. Proceedings of the First FM Goneral Aviation Research and Development Conference. Washington, $D$ : Federal Aviation Administration, August 1977.

Roche, R. J. FSS modemization. Proceedings of the First FM Ceneral Aviation Research and Development Conference. Washington, $\mathcal{D}$ : Federal Aviation Administration, August 1977.

Rogers, J. C, \& Armstrong, R. Use of tuman engineering standards in design. Human Factors, 1977, 19, 15-24.

Rogers, J. C, \& Pegden, C. D Fomatting and organization of a human engineering standard, Human Factors, 1977, 19, 55-62. 
Roscoe, S. N. Alrtome displays for flight and navigation. Hurnen Factors. 1968, 10, $321-332$.

Roscoe, So N. When day is cone and shadows fall, we miss the aiport most of all. Human Factors, 1979, 21, 721-732.

Roscoe, S. No Aviation Psychology. Ames: lowa State University Press, in press.

Roscoe, S. No, \& Hopkins, C. O. Enhancerment of human effectiveness in system design, training, and cperation (ARL-75-21). Savoy, IL: University of Illinois at Urbana-Champaign, July 1975. (NTIS Nb. AD-A023 941)

Roskam, J. Opportunities for progress in general aviation technology (AIM Paper 75-292). Washington, D: American Institute of Aeronautics and Astronautics, February 1975.

Roskam, J., \& Kohlman, D L. The grudging progress of lightolane design. Air Progress, $1974,34(1), 28-37$.

Rouse, W. B. Systems engineering models of humsn-machine interactions. New York: North Holland Pulishing Co., 1.980.

Rowland, C. E, \& Reichuein, C. T. Functional analysis of pilot warning instrument characteristics (FA-RD-71-59). Washington, DC: Federal Aviation Administration, September 1971. (NTIS Nb. AD-730 516)

Rudolph, J. Operation save-a-life. FMA Aviation News, 197\$, 13(2), 10-11.

Scheftel, P. 1. Influencing factors on future aircraft with emphasis on the cockpit (Unoubllshed manuscript). Washington, $D$ : Federal Aviation Administration, 1979.

Schendel, J. D, Shields, J. L., \& Katz, M. S. Retention of motor skills: A review (Technical Paper 313). Alexandria, VA: U.S. Army Research Institute for the Behavioral and Social Sciences, September 1978.

Schiff, B. Cockpit standardization. The AOPA Pibt, 1980, 23(7), 41-44.

Schmenk, 1. C. Ceneral aviation activity and ovionics survey (TSC-FAA-79-16). Cambridge, MA: Transportation Safety Center, pril 1979.

Seltzer, L. Z. A study of the effect of time on the instrument skill of the private and commercial pilot (FAA-DS-70-12). Washington, $D$ : Federal Aviation Administration, March 1971.

Semple, C. A., Cotton, J. C., \& Sullivan, $D_{0}$ 1. Aircrew training device instructional suppor features (Tech. Rep. CRC-3047C). Westlake Village, CA: Canyon Research Croup, Inc., February 1980. 
Sermple, C. A, Hennessy, R. T., Sanders, M. So, Cross, B. K., Beith, B. $L_{\text {, }}$ \& McCauley, $M$. E. Aircrew training device fidelity features (CRC-TR-3041B). Westlake Village, CA: Canyon Research Croup, Inc., February 1980.

Shaw, J. Mo, \& Allen, C Ro Optimization of the oxclpit environment and the crew-cockpit interface. Proceedin s from Advison Croup for Aerospace Research and Development Conference on Problems in $t$ oc it Esvironment. Neuilly sur Seine, France: North Atlantic Treaty Organization, Advisory Croup for Aerospace Research and Development, November 1968.

Shelnute, 1. B. A consideration of Army training device proficiency assessment capabilities (TR-78-A20). Alexandria, VA: U.S. Army Research Institute for the Behavioral and Social Sciences, June 1978. (NTIS Nb. AD-A0S6 191)

Siegel, ^ 1., Musetti, L. L., Fedeman, P. J., Pfeiffer, M. C., Wiesen, J. P., Deleo, P. l., \& Shepperd, W. R. Criterion-referenced testing: Review, evaluation, and extension (AFHRL-TR-78-71). Brooks AFB, TX: Air force Human Resources Laboratory, August 1979.

Siegel, P. Vo, \& Mohler S. R. Medical factors in U.S. general aviation accidents (FAA$A M-69-2)$. Washington, $D C:$ Federal Aviation Administration, June 1969.

Silver, B. $W$. The future of safety in general oviation. AlM Student Joumal, 1976, $14(3), 12-15$.

Sincoff, M. 2., \& Dajani, J. S Ceneral aviation and community develooment. Norfolk, VA: Old Dominion University, $19 \overline{75 .}$

Smith, F. K. An appreciation of the social, economic, and political issues of general aviation (CA-300-133). Washington, $D$ : Federal Aviation Administration, June 1977.

Smith, Ho P. $R$ A simulator study of the interaction of pilot norkload with errors, vigilance end decisions (NASA-TM-78872). Washington, $\mathcal{X}$ : National Aeronausics and Space Administration, January 1979.

Smith, H. P. R., \& Parker, B. D. The interaction 'of cormmenication with cockpit workload and safety. In Aeromedical aspects of radio commmication and flight safety (Advisory Report 19). Neuilly sur Seine, France: North Aslantic Treaty Organization, Advisory Crow for Aerospace Research and Development, December 1969. (NTIS No. N70-16962)

Smith, R. C., \& Melton, C. E. Effects of a ground trainer on the psychological and physiological states of students in private pilot training. Washington, $D C$ : Federal Aviation Administration, March 1976. (NTIS Nb. AD-AO24 704)

Smish, R. K. State of the art sumey of technologies apolicable to NASA's aeronautics, avionics and controls program (NASA-CR-159050). Washington, DC: National Aeronautics and Space Administration, May 1979. (NTIS No. N79-27087)

Smyth, R. K. Avionics and controls in review. Astronautics and Aeronautics, 1980, 18(4), $40-52$. 
Smode, ^ F. Training device design: Human factors reguirements in the technical

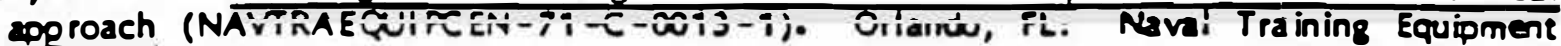
Center, Nugust 1972.

Smode, A Fo, \& Hall, E R. Translating information requirements into training device fidelity requirements. Proceedings of the 19th Annual Meeting of the Human Factors Society. Santa Monica, CA: Heman Factors Society, October 1975.

Sower, J. F. Inproved weather data for Eeneral aviation coperations. Proceedings of the First FM Ceneral Aviation Research and Development Conference. Washington, $D$ : Federal Aviation Administ ration, August 1977.

Stanek,. P. Study of capabilities, necessary characteristics and effectiveness of pilot Brow trainers, Vol. I (FM-RD-72-127,1). Washington, DC: Federal Aviation Administration, Jantury 1973a. (NTIS No. AD-735 681)

Stanek, P. Study of capabilities, necessary characteristics and effectiveness of pilot grow trainers, Vol. II (FM-RD-72-127,II). Washington, DC: Federal Aviation Administration, January 19736. (NTIS No. AD-755 682)

Strickler, M. Ko, \& Esspuchler, J. J. Ceneral oviation safety: Fact and fiction. AlAA Student Joumal, 1975, 12, 8-12.

Swezey, R. Wo, \& Pearlstein, R. B. Culdebook for developing criterion-referenced tests. Arlington, VA: U.S. Amry Research Institute for the Behavioral and Social Sciences, August 1975.

Tashken, M. (Ed.). Transcription of the workshap on general aviation-advanced avionics systems (NASA-CR-137861). Washington, DC: National Aeronautics and Space Administration, May 1976. (NTIS Nb. N76-28233)

Teper, C. L., Hoh, R. H. \& Smyth, R. K. Preliminary candidate advanced avionics system (PCMS), final report (NASA CR-152026). Washington, $D$ : National te ronautics and Soace Administration, September 1977.

Thielges, J. R., \& Matheny, W. C. Analysis of visual discriminations for helicopter control (Tech. Rep. 71-13). Alexandria, VA: Human Resources Research Organization, June 1971.

Thurston, D. B. Design for safety. New York: MeCraw-Hill, 1980.

Tobias, 1. V. Auditory effects of noise on airerew personnel (FA-AM-72-32). Oklatioma City, OK: Federal Aviation Administration Civial Aeromedical Institute, November 1972.

Trammel, $A$. The three faces of landing accidents. Business and Commericial Aviation, $1974,34(6), 86-89$.

Trollip, S. An evaluation of a complex computer-based flight procedures trainer (ARL77-1). Savoy, IL: Illinois University at Urbana-Champaign, January 1977. (NTIS No. $A D-A 043246$ ) 
Van Cott, $H_{0}$ P., \& Kincade, R. C. (Eds.). Human engineering guide to equipment design (Rev. ed.). Washington, DC: U.S. Covernment Printing Office, 1972.

Vineberg, R., \& Joyner, J. N. Instructional system development (ISD) in the armed services: Methodology and application (HumRRO-TR-80-1). Alexandria, VA: Human Resources Research Organization, January 1980.

Viteles, M. A. The aircraft pilot, five years of research: A summary of outcomes. Washington, $\overline{\mathcal{C}:}$ National Research Council, Iune 1945.

Weislogel, C. So, \& Miller, J. M. Study to determine the coerational profile and mission of the certificated instrument rated private and commercial pilot (FAA-RD-70-51). Washington, $D C:$. Federal Aviation Administration, July 1970.

Welsh, K. W., Vaughan, I. A., \& Rasmussen, P. C. Survey of cockpit visual problems of senior pilots (FAA-AM-77-2). Washington, $D C$ : Federal Aviation Administration, Decernber 1976. (NTIS No. AD-A037 587)

Wiener, E. L. Aircraft collisions. Proceedings of the 23rd Annual Meeting of the Human Factors Society. Santa Monica, CA: Human Factors Society, October 1979.

Wiener, E. L. Controlled flight into terrain accidents: System-induced errors. Human Factors, 1977, 19, 171-182.

Williams, A. C. Discrimination and manipulation in soal-directed instrument flight. Aviation Research Monographs, 1971, 1(1), 1-47.

Young, L. Lo, Jensen, R. S., \& Treichel, C. W. Uses of a visual landing system in primary flight training (ARL-73-26). Savoy, IL: University of lllinois at Urbana-Champaign, October 1973.

Zeller, A. F. Three decades of USAF efforts to reduce human error accidents 1947-1977. Paper presented at the 35th Specialists Aerospace Medical Panel Meeting of NATO Advisory Croup for Aerospace Research and Development, Paris, November 1978.

Proceedings of The First Symposium On Aviation Psychology, Ohio State University, 21-22 April 1981

Proceedings of The Second Symposium On Aviation Psychology, Ohio State University, 25-28 April 1983 


\section{APPENDIX B}

Selected References On Part-Task Training And Aviation Simulation Applications

Adams, J. A. Theoretical issues for knowledge of results. In G. Stelmach

(Ed). Information Processing in Motor Control and Learning. New York:

Academic Press, 1978.

Adams, J.A. A closed-loop theory of motor behavior. Journal of Motor Behavior, 1971, 3, 111-149.

Adams, J.A. Part Trainers. In G. Finch (Ed.). Educational and rraining Media: A symposium. Washington, DC; National Academy of Science - National. Research Council, Publication $789,1960$.

Adams, J.A. and Hufford, L.E. Effects of programmed perceptual training on the learning of contact landing skills. port Washington, NY: U.S. Naval Training Device Center Tech. RPE. NAVTRA.DEVCEN, 247-3, 1961.

Ammons, R.B., Ammons, C.H. and Morgan, R.L. Transfer of skill and decremental factors along the speed dimension in rotary pursuit. Perceptual and Motor Skil1s, 1955, 6, 43.

Arnoult, M.D. Stimulus predifferentiation: Some generalizations and hypothesis. Psychological Bulletin, $1957, \underline{54}(4), 339-350$.

Bailey, J.S., Hughes, R.G. and Jones, W.E. Application of backinard chaining. to air-to-surface weapons delivery craining. Williams AFG, AZ: Operations Training Division, Human Resources Laboratory, AFHRL-TR-79-63, April, 1932.

Bickley, w.k. Optimizing simulator-aircraft training mixes. proceedings of 2nd Interservice/Industry Training Equipmer: Conference Exhibition, Ft. Rucxer, AL: Army Reseaszn Institute, November, 1980.

Bilodeau, I. MCD. Accuracy of a simple posilioning response with variation in the number of trials by whith knowlesge of results is delayed. American Journal of psychology, $1956, \underline{69}, 434-437$.

Boulter, L.R. Evaluation of mechanisms in delay of. knowledge of results. Canadian Journal of Psychology, 1954, 13. $281-291$.

Brictson, C. A., \& Burger, W. J. Transfer of training effectiveness: A-7E night carrier landing trainer (NCLT) device 2F103. NAVTRAEQUIPCEN 74-C-0079-1, August 1976. 
Briggs, G.E. On the scheduling of training conditions for the acquisition and transfer of perceptual motor skills. Port Washington, NY: Naval Training Device Center, Tech. Rpt. NAVTRADEVCEN, 835-1, 1951.

Briggs, G.E. and Brogden, W.J. The effect of component practice on performance of a lever-positioning skill. Journal of Experimental Psychology, $1954,48,375-380$.

Briggs, G.E. and Naylor, J.C. The relative efficiency of several training methods as a function of transfer cask complexity. Journal of Experimental Psychology, 1952, 64, 535-512.

Briggs, G.E. and Rockway, M.R. Learning and performance as 3 function of the percentage of pursuit component in a tracking display. Journal of Experimental psychoiogy, 1966, 71, 165-159.

Briggs, G.E. and waters, L.K. Training and transfer as a Eunction of component interaction. Journal of Experimental psychology, $1958, \underline{56}, 492-500$.

Caro, P. W. Flight evaluation procedures and quality control of training (HumRRO Tech. Rep. 68-3). Alexandria, Va.: Human Resources Research Organization, March 1968.

Caro, P. W. Platform motion and simulator training effectiveness. 10th NTEC/ Industry Conference Proceedings. Orlando, Fla.: Naval Training Equipment Center, November 1977.

Caro, P.W. Some factors influencing transfer of simulator training. Professional Paper HUMRRO-PP-1-76. Alexandria, VA: Human Resources Research Organization, August 1976.

Caro, P.W. Some current problems in simulator design testing and use. Professional Paper HUMRRO-PP-2-77. Alexandria, VA: Human Resources Research Organization, March 1977.

Cl ausen, P. EA-6B Crash on Nimitz attributed to pilot error. Aviation Week and Space Technology, August 16, 1982, 117(7), 22-23.

CNATRA instruction 1542.20B. Curriculum, Advanced Jet (TA-4J). Chief of Naval Air Training, NAS Corpus Christi, Tex., 20 September 1976.

Collyer, S. C., and Chambers, W. S. AWAVS, a research facility for defining flight trainer visual requirements. Proceedings of the Human Factors Society, 22nd Annual Meeting, Detroit 1978.

Cronbach, L. J., and Snow, R. E. Aptitudes and Instructional Methods. New York: Irvington. 
Dashiell, J.F. An experimental isolation of higher level habits. Journal of Experimental psychology, 1924, I. $391-397$.

Day, R.H. Relative task difficulty and transfer of training in skilled performance. psychological Bulletin, 1956, 53. $160-168$.

Gagne, R.M., Baker, K.E. and Foster, H. On the relation between similarity and transfer of training in the learning of discriminative motor tasks. Psychological Review, ig5:, 57. 67-79.

Gagne, R.M. and Foster, H. Transfer of training from practice on components in $a$ motor skill. Journal of Experimental Psychology, 1949, 39, 47-68.

Gaines, B.R. Teaching machines for ferceptual notor skills. In Irwin, D. and Leedhain, J. (Eds.) Aspects of educational rechnology. The proceedings of the Programmed Learning Conferense held at Loughborough, 15-18 April, 1965, London: Meuthen, 19 isi.

Germas, J.E. and Baker, J.D. Embedded training: veilization of tactical computers to train tactical computer operations. Alexanjria, VA: U.S. Army Research Insticute for the Banavioral and Social Scienses, Teisnica! Ruport 542, July, 1990 .

Gibson, E.J. Improvement in peripheral judzments as a function of controlled practice or learning. Psycholoyical. Bulletin, 1953, 50, 401-431.

Gibson, E.J. Principles of perceprua! learning and development. New York: Appleton-Century-Croís, 1969.

Goldstein, 1. L. Training in work organizations. In M. R. Rosenzweig and $L$.

W. Porter (Eds). Annual Review of Psychology, 1980, 31, 229-272.

sordon, N.B. Learning a moror rask under varied display conditions. Journal of Experimental Psychology, 1959. 57. $55-73$.

Cray, T. H., \& Fuller, R. R. Effects of simulator training and platform motion on air-to-surface meapons delivery training (AFHRL-TR-77-29). Williams AFB, Ariz.: Flying Training Division, Air Force Human Resources Laboratory, July 1977.

Hagin, W. V. Platform motion in flight simulators: Critical or nice? Proceedings of the Society for Applied Leaming Technology. Washington, D. C., 1976. 
Hagin, W. V., Prophet, W. W., \& Corley, W. E. Transfer of training effectiveness evaluation $\left(T^{2} E^{2}\right)$ : U.S. Naw Device 2B35. Phase I report: Evaluation plan (Tech. Report TR 78-02). Pensacola, Fla.: Seville Research Corporation, March 1978.

Hays, W.L. Statistics. New York: Holt, Rinehart and Winston, 1963. Hennessy, R. T., Lintern, G., and Collyer, S. C. Unconventional visual displays for flight training. Orlando, FL: NAVTRAEQUIPCEN 78-C-0060-5, November, 1981.

Holding, D.H. Transfer between difficult and early rasks. British Journal of Psychology, 1962, 53, 397-402.

Holding, D.H. principles of Training. Oxford: Pergamon Press, 1965.

Holding, D.H. An approximate transfer surface. Journal of Motor Behavior, 1976,, $1-9$.

Holding, D.H. Learning without errors. In L. Smith (Ed.), Psychology of Motor Learning. Chicago, IL: The Athletic. Institute, 1970.

Holmgren, J.E., Hilligoss, R.E., Swezey, R.'. and Eakins, R.C., Training effectiveness and retention of training extension course (TEC) instruction in the combat areas. Alexandria, VA: U. S. Army Research Insticute for the Behavioral und Social Sciences, Research Report 1208, April 1979.

House, B.J. and zeaman, D. Transfer of a discrimination from objects to patterns. Journal of Experinental psycholocy, $1950,59,298-302$.

tiughes, R.G., Lintern, G., Wightman, D.C., Brooks, R.B. and Singleton, J. Applications of simulator fretze to sarric: glideslope tracking instruction, 0rlando, FL: Naval Training Equipment Center, Rpt. No. 78-C-ca60-9/ AEHRL-TR-32-3, 1931 .

Hughes, R.G. Enabling features versus instructional features in flying training simulation. Proceedings of the lst Interservice/Industry Training Equipment Conference. Orlando, FL: NAVTRAEQUIPCEN IH-3I6, T979.

Hughe s, R. G., Hannan, S., and Jones, W. Appl ication of flight simulator record/playback feature. Williams AFB, AZ: Operations Training Oivision, Air Force Human Resources Laboratory, AFHRL-TR-79-52, December, 1979.

Hughes, R. G., Lintern, G., Wightman, D. C., and Brooks, R. B. On the use of a flight simulator's freeze feature during acquisition of a carrier landing task. Proceeding of the 3rd Interservice/Industry Training Equipment conference. Orlando, FL: Naval Training Equipment Center, November 1981.

Human factors evaluation $2 \mathrm{~F} 90$ visual system, contract N61339-72-C-0192. Daytona Beach, Fla.: Ceneral Electric Company, May 1973. 
Human Resources Research Organization. Operational content training in individual technical skills. Alexandria, VA: Author, Professional Paper 35-69, December, 1969.

Jaeger, R.J.. Agarwal, G.C. and Gottlieb, G.L. Predictor operator in pursuit and compensatory tracking. Human Factors, 1980, 22, 497-506.

Kaul, C.E., Collyer, S.C. and Lintern, G. Gl ideslope descent-rate cuing to aid carrier landings. NAVTRAEQUIPCEN IH-322. Orlando, FL: Naval Training Equipment Center, October 1980.

Kelley, C.R. What is adaptive training? Human Factors, 1959, 11. 547-556.

Kennedy, R. S., Bittner, A. C., and Jones, M. B. Video-game and conventional tracking. Perceptual and Motor Skills, 1981, 53, p. 310.

Kennedy, R. S., Bittner, A. C., Harbeson, N., and Jones, M. B. Television computer games: A 'New Look' at perfomance testing. Aviation, Space and Environmental Medicine, January, 1982.

Levine, M. Transfer of tracking performance as a function of delay between the control and display. Wiright patcerson AFB, OH. USAF Wright Air Developinent Center Tech. Rpt. $53-237,1953$.

-ewis, D., MCAllister, D.E. and Bechroldt, H.D. Correlational study of performance during sucsessive phases of practive on the standard and reversed tasks on the SAM complex soordinaror. Journal of Psyshology, 1953, 36, 111-126.

Lintern, G. Transfer of landing skill after training with supplementary visual cuis. Human Factors, 1980, 22, 81-88.

Lintern, C. and Gopher, D. Adaptive training of perceptual motor skills: Issues, results and future directions.

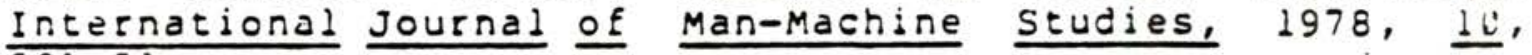
$521-5 i$.

Lintern, G., and Kennedy, R. S. A video game as a covariate for carrier landing research. Manuscript submitted to the Eighth Psychology in the DoD Symposium, April, 1982.

Lintern, C. and Roseoe, S.N. Visual cue augmentation in contact flight simulation. In S.N. Roscoe, Aviation Psychology, imes, IA: The Iowa stase University Priss, 1980 .

Lintern, G., Thomley, K., Nelson, B., and Rossoe, S.N. tontent, variety, and augmentation of simuleted visual scenes for teaching air-to-ground attask. Orlando, FL: Nava: Training Equipment Center, Tech. Rpt. NAVTRAzQUIPCE: $81-\mathrm{C}-0185-3,1984$. 
Martin, E. L., \& Waag, W. L. Cont ributions of motion to simulator training effectiveness: Study 1-Basic contact (AFHRL-TR-78-15). Williams AFB, Ariz.: Flying Training Division, Air Force thman Resources Laboratory, 1978.

Martin, E. L., \& Waag, W. L. Contributions of motion to simulator training effectiveness: Study II-aerobatics (AFHRL-TR-78-52). Williams AFB, Ariz.: Flying Training Division, Air Force Human Resources Laboratory, 1978.

Munro, A., Fehling, M.R., Blais, P. and Towne, D.M. Intensive and non-intensive instruction in dynamis skill training. Redondo Beach, CA: Behavioral Technology Laboratories, Department of psychology, University of southern California, Tech. Rpt. 76, September, 1981.

NATOPS manual: Landing signal officer. Department of the Navy, Office of Chief of Naval Operations, 15 November 1975.

Naylor, J.C. Parameters affecting the relative efficiensy of part and whole training methods. A review of the literature. Columbus, OH: Ohio State University Researsh Foundation, Laboratory of Aviation Psychology, Tech. Rpe. NAVTRADEVCEN $950-1,1952$.

Naylor, J.C. and Briggs, G.E. Effects of task complexity and tusk organization on the relative efficiency of part arid whole trainin' methods. Journal of Experimental Psychology, 1953, 55, 217-224.

Noble, M., Trumbo, D., Ulrich, L. and Cross, K. Task predictabilizy and the development of tracking skill under extended practice. Journal of Experimental psychology, $1966, \underline{72}, 85-94$.

Norman, D.A. Adaptive training of manual control: Relation of adaptive scrieme parameters to task parameters. Orlando, FL. Naval Training Equipment Center, Tech. Rpt. NAVTRAEQUIPCEN 70-C-0215-1, 1973.

Norman, D.A., Lowes, A.L. and Matheny, iv.C. Adaptive training of manual control. Orlando, FL: Naval Training Eevile Center, Tech. Rọ. NAVTRADEVCEN 69-C-U150-1, 1972.

Payne, R.B. Functional properties of supplementary feedback stimuli. Journal of Motor Behavior, 1970, 2. 37-43.

Payne, R.B., and Artley, C.W. Facilitation of psychomotor learning by classically differentiated feedback cues. Journal of Motor Behavior, $1972,4,47-55$.

Payne, R.B. and Dunman, L.S. Effects of classical differentiation on the functional properties of supplementary feedback cues. Journal of Motor Behavior, 1974, 6, 47-52. 
Payne, R.B. and Richardson, E.T. Effects of classically differentiated supplementary feedback cues on tracking skill. Journal of Motor Behavior, 1972, 4, 257-261.

Payne, T. Ao, Kirsch, D. L., \& Temple, C. A. Experiments to evaluate advanced flight simulation in air combat pilot training, Volume 1. Transfer of leaming experiment. Hawhome, Galif.: Northrop Corporation, 1976.

Pow, R.W. The acquisition of hierarchial control over the temporal organization of a skill. Journal of Experimencal Psychology, 1956, 71, 754-771.

Poulton, E.C. Tracking skill and manual sontrol. New York: Academis press, 1974 .

Povenmize, H.K. and Roscoe, S.N. incremental transfer effectiveness of a ground based general aviation trainer. Human Factors, 1973, 15, 534-542.

Povenmire, H. K., Alvares, K. M., \& Damos, D. L. Observer-observer flight check reliability (Tech. Rep. LF-70-2). Savoy, III.: Aviation Research Laboratory, University of Illinois, October 1970.

Prophet, W. W. Performance measurement in helicopter training and operations (HumRRO Professional Paper 10-72). Alexandria, Va.: Human Resources Research Organization, Anril 1972.

Reynolds, B. and Bilodeau, I. MCD. Acquisition and retention of three psychomotor tests as a function of distribution of practice during acquisition. Journal of Experimental Psychology, 1952, 44, 19-26.

Roscoe, S.N. and Williges, B.H. Measurement of transfer of training. In Stanley N. Roscoe (Ed.), Aviation Psychology, Ames, IO: Iowa State University Press: Ames IO, 1930 .

Salthouse, T.A. and Prill, K. Analysis of a perceptual skill. Journal of Experimental Psychology: Human perception and performance, $1983, \underline{9}, 607-621$.

Schendel, J.D. and Newell, K.M. On processing the information from knowledge of results. Journal of Motor Behavior, $1976, \underline{8}, 251-255$.

schendel, J.D., Shields, J.L. and Katz, M.S. Retention of motor skills: review. Alexandria, VA: U.S. Army Research Institute for the Behavioral and Social Sciences. Tech. Paper 313,1978 . 
Schneider, W. Automatic control processing concepts and their implications for the training of skills. Champaign, IL: Human Atrention Research Laboratory, Psychology Department, University of Illinois. Report HARL-ONR-8101, April, 1982.

Scientific Advisory Board, U.S. Air Force. USAF Scientific Advisory Board report of the ad hoc committee on Air Force simulation needs. Scientific Advisory Board, U.S. Air Force, lanuary 1973.

Singer, R. N. Motor skills and learning strategies. In H. F. O'Neil, Jr. (Ed). Learning Strategies. New, York: Academic Press, 197.

Sheppard, D.J. Visual and part-task manipulations for teaching simulated carrier landings. Orlando, Fl: Naval Training Equipment Center, Tech. Rpt. NAVTRAEQUIPCEN 81-C-0105-9, 1984 .

Shiffrin, R.M. and Schneider, W. Controlled and automatic human information processing: II. Perceptual learning, automatic attending and a general theory. Psychological Review, 1977, 84, 127-190.

Smith, R.L., Pence, G.G., Queen, J.E., and Wulfeck, J.W. Effect of a predictor instrument on learning to land a simulated jet trainer. Inglewood, CA: Dunlap and Associates, Inc., 1974.

Snow, R.E. Aptitudes and instructional methods: Research on individual differences in learning--related processes. Stanford, CA: Stanford University School of Education, 1980.

Smith, J. F., Flexman, R. E., \& Houston, R. C. Development of an objective method of recording flight performance (Tech. Rep. HRRC 52-15). Lackland AFB, Tex.: USAF HRRC, December 1952.

Stammers, R.B. Part and whole practice for a tracking task: effects of task variables and amount of practice. Perceptual and Motor skills, 1980, 50, 203-210.

Tatsuoka, M.M. Discriminant analysis: The study of group differences. Champaign, IL: Institute for Personality and Ability Testing, 1970.

Trumbo, D.. Noble, M.. Cross, K. and Ulrish, R. Task predictability in the organization, acquisition and retention of tracking skill. Journal of Experimental psychology, 1965, 70, 252-263.

USAF Tactical Air Cormand. A continuation training program using the simulator for air-to-air combat (SAAC). Nellis AFB, Nevo: Tactical Fighter Weapons Center, March 1976. 
USAF Tactical Air Command. Evaluation of the simulator for air-to-air combat (SAAC) FOT\&E. Final Report. Eglin AFB, Fla.: Tactical Air Warfare Center, 1977.

USAF Tactical Air Command. Final Report: Tactical Air Command special project to develop and evaluate a simulator air combat training program (Phase I) (TAC ACES I). Nellis AFB, Nev.: Tactical Fighter Weapons Center, February 1977.

irestra, D.P. Investigation of simulator design features for carrier landing: II. In-simulator transfer of training. Orlando, Fl: Naval Training Equipment Center, Tech. Rpt. NAVTRAEQUIPCEN 81-C-0105-1, December, 1982.

Wheton, C.R., Rose, A.M., Fingerman, P.W., Korotkin, A.C. and Holding, D.H. Evaluation of the effectiveness of training devices: Literature review and preliminary model. U.S. Army Research Insticute for the Behavioral and Social Sciences, Research Memorandum 76-6. 1976.

Wightman, D.C. Part-task training strategies in simulated carrier landing final approach training. Orlando, $F L$ : Naval Training Equipment Center, Tech. Rpe. NAVTRAEQUIPCEN IH-347, November, 1983.

Wightman, D. C., and Lintern, G. Part-Task Training of Tracking in Manual Control. Orlando, Florida: NAVTRAEQUIPCEN 81-C-0105-2. August, 1983.

williges, R.C. and Baron. M. L. Transfer assessment using a between-subjects central-composite design. Human Factors, $1973,15,311-319$.

Winer, B. J. Statistical Principles in Experimental Design. and Edition. New York: McGraw-HiT, 1971. 